\title{
Local Wisdom Pikukuh Sapuluh Culture and Environment Conservation In Baduy Tribe
}

\author{
Mega Halmahera ${ }^{1}$, Anggi Septiya Purnama ${ }^{2}$, Fuad Hasyim ${ }^{3}$, Andi Irwan Benardi ${ }^{4}$ \\ \{megahalmahera98@gmail.com ${ }^{1}$, septiyaanggii@gmail.com ${ }^{2}$, Fuadhasyim690@gmail.com ${ }^{3}$, \\ andi@mail.unnes.ac.id $\left.{ }^{4}\right\}$ \\ 1,2,3,4 Universitas Negeri Semarang, Indonesia
}

\begin{abstract}
Baduy Tribe is in Kanekes Village, Leuwidamar Subdistrict, Lebak District, Banten. The tribe that lives depends on nature and always maintains the balance of nature, through traditional rules and Pikukuh sapuluh is the basis of life guidelines and produces Baduy culture both in thinking, acting and behaving. The study, "Local Wisdom Pikukuh Sapuluh Culture And Environment Conservation In Baduy Tribe" is intended to find out how the environmental and cultural conservation of the Baduy community towards the environment and future generations (character inheritance), and to find out how the Baduy community maintains a culture with Pikukuh traditional rules especially Pikukuh Sapuluh that applies and preserves the culture of the influences that come outside and to find out land use in Baduy Dalam and Baduy Luar related to the use of production forests and the riles that apply to prohibited forests. The research conducted was development research from previous researchers. The type of research used is qualitative research with interviews, observation, field surveys, and documentation using triangulation methods as data analysis techniques.
\end{abstract}

Keywords: Baduy Tribe, Pikukuh Sapuluh, Local Wisdom, Environmental-Cultural Conservation, Character Inheritance

\section{Introduction}

Indonesia is an archipelago formed byodiversity called plural society. This pluralism is interwoven in one Indonesian nation's bond as a whole and sovereign nation. According to the Big Indonesian Dictionary (KBBI) diversity comes from the word variant which means many types, various, patterned. Forms of diversity in Indonesia include religion, culture, language, and ethnicity.

Modernization of the era can not be separated from the advancement of science and technology (science and technology). As time went on, the life order as a form of culture which became the guideline of people's lives gradually began to erode. The resulting bad impact is not creating harmony with nature as a place and provider of human needs, if its existence is disturbed there will be an imbalance, it impacts on human life.

The Baduy are an ethnic group that lives side by side with nature, the Baduy are known as traditional tribes who alienate themselves from the outside world and the development of science and technology. Amid the modernization of the era, the Baduy Tribe still adhered to the prevailing rules of customs known as Pikukuh. All daily activities can not be separated from the influence of Pikukuh which has been valid for generations.

By doing the research, "Local Wisdom Pikukuh Sapuluh Culture And Environment Conservation In Baduy Tribe" is expected to be able to find out how the environment and cultural conservation of the Baduy Tribe towards their natural and future generations 
(character inheritance), also to know how to maintain their culture with the Pikukuh Sapuluh traditional rules applies and outside influences that come. The research was conducted by the method of qualitative research, namely triangulation, including; observations in the form of field surveys and observations (observations), interviews and documentation as a medium for disseminating information.

\section{Research Method}

This research is a qualitative study using interviews, observation, field surveys, and documentation as data collection techniques, then processed using triangulation techniques, and described by the description method. The research was conducted as a method of developing research that already existed in the Baduy Tribe which was located in the Kendeng Mountains of Kanekes Village, Leuwidamar Subdistrict, Lebak District, Banten to collect data directly (primary data) and literature studies for data collection (secondary data).

Norman K. Denkin licensed triangulation in a combination of combination methods to study interrelated phenomena from different perspectives and perspectives. Based on the formulation of the problem raised, the focus of the research strategy is to describe the development of environmental and cultural conservation, where research is conducted to be able to study the research conducted in Baduy field, using qualitative methods and triangulation methods.

1. Interview according to Sugiyono [1] is a source of data directly in person (face to face) or telephone. Interviews were conducted with informants as resource persons, interviews were conducted with Village Head (Puun) and Elder (Kokolotan) of Baduy, Baduy communities, tourists, and communities around Baduy.

2. Observation according to Anas Sugiono [1] generally states that observation is a way to collect information material (data) which is carried out by systematically observing and recording the phenomena that are being targeted for observation. Observations made in the form of observations and field surveys in the Kanekes Village, Leuwidamar Subdistrict, Lebak District, Banten.

3. A field survey is a method of collecting data directly conducted in the field. Field surveys are carried out by comparing data sourced from secondary data that has been collected with conditions on the ground.

4. Documentation according to Sukmadinata [1] is a data collection technique, by collecting and analyzing documents, both written documents, images, and electronics. Documentation is done as supporting data when conducting research.

A descriptive analysis technique according to Sora is an analysis technique used to analyze data by describing data that has been collected improvised without any intention of generalizing the results of the study. The descriptive analysis technique is done by doing the stages:

1. Stage of problem formulation.

2. The stage determines the type of information needed.

3. The stage determines the data collection procedure.

4. The stage determines the procedure for processing data information.

5. The stage draws research conclusions.

The stages of research carried out are: 


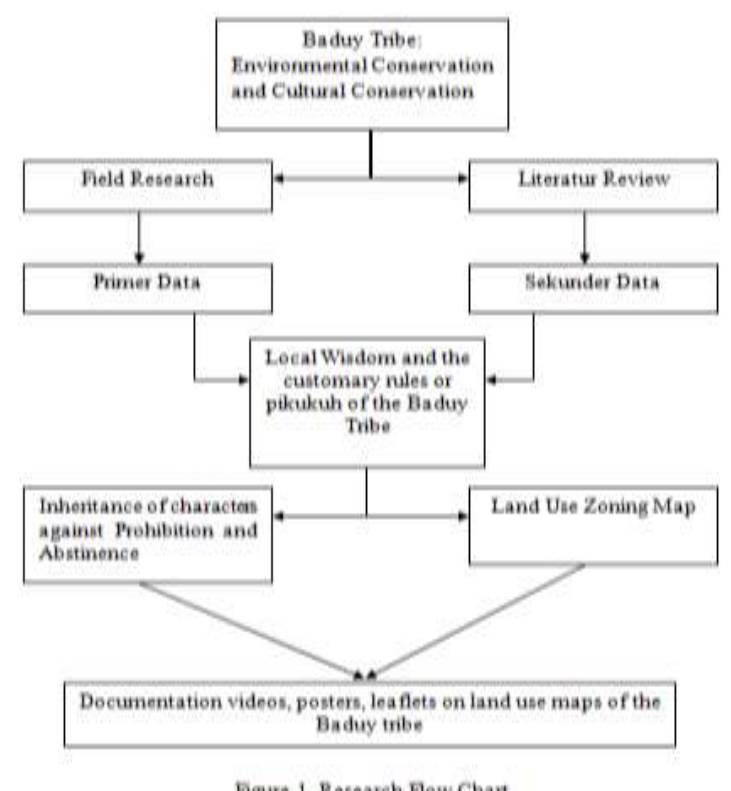

Figure 1. Research Flow Char

\section{Result and Discussion}

\subsection{Baduy Tribe}

The Baduy are ethnic groups that live side by side with nature, located in the Kendeng Mountains, Kanekes Village, Leuwidamar Subdistrict, Lebak District, Banten. Kendeng Mountains are mostly forests, both protected forests and production forests. The geographical location of the Baduy is $6^{\circ} 27^{\prime} 27$ " $-6^{\circ} 30^{\prime} 0^{\prime \prime}$ LS and 108 $3^{\prime} 9^{\prime \prime}-106^{\circ} 4^{\prime} 55^{\prime \prime}$ BT. Typical local wisdom, especially in efforts to conserve and preserve the environment in processing nature and culture based on the provisions of adat and Pikukuh which are embedded in the soul and carried out with full awareness. The Baduy Tribe is divided into two territorial regions, namely the Baduy Luar or the Baduy Panaping and the Baduy Dalam or the Tangtu Baduy. The Baduy Tribe is led by a village head or called Puun who lives in the Baduy Dalam. There are three Puun in Baduy Dalam in Kampung Cibeo, Cikartawan, and Cikeusik, which are central areas. The Baduy religion is Sunda Wiwitan (belief in nature and ancestral spirits), namely the belief that the Baduy community is the person who was first created as a filler of the world and resides on earth (Suhartini [2]), the Baduy Tribe considers the element responsible for maintaining and maintaining the earth. This belief is related to the religion adopted by the Baduy Tribe, namely Sunda Wiwitan.

According to Jaro Saijan, the village head of Kampung Kaduketug, the number of Baduy people spread in Kanekes village is around 12 thousand people, with an area of 5,101.85 ha [2]. Map of Baduy region taken at the research location. 


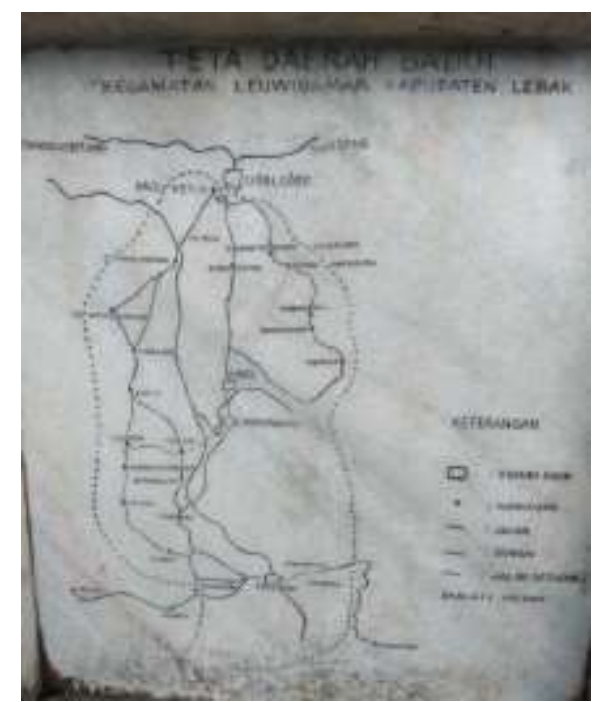

Source: Team documentation

Picture2. Map of the Baduy area

The difference between the two regions can be seen from the distinctive clothing and shape of the house. Baduy Luar is characterized by wearing black clothes and headbands and Baduy Dalam with distinctive white clothing and headbands. Then the difference in making a house where the Baduy Luar uses nails to connect the frame of the house, while the Baduy Dalam only uses ropes to connect the wood to make the frame of the house. The type of Baduy house is a stilt house made of woven bamboo (cubicle), the house that is made of the shape adjusts to the existing morphology, if the land is sloping, the addition of stones is done to make the land flat as shown below:

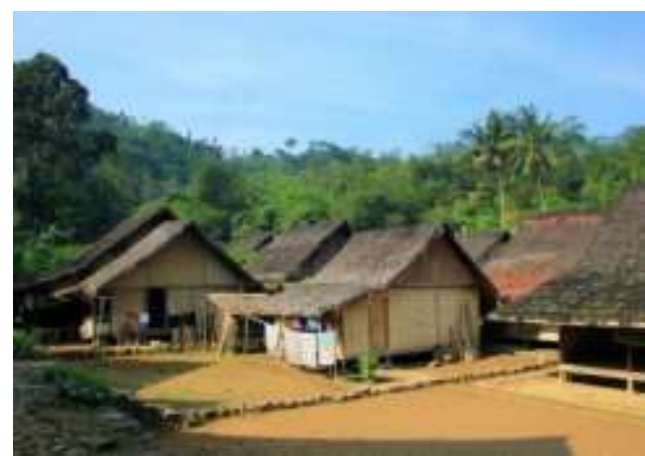

3.(a)

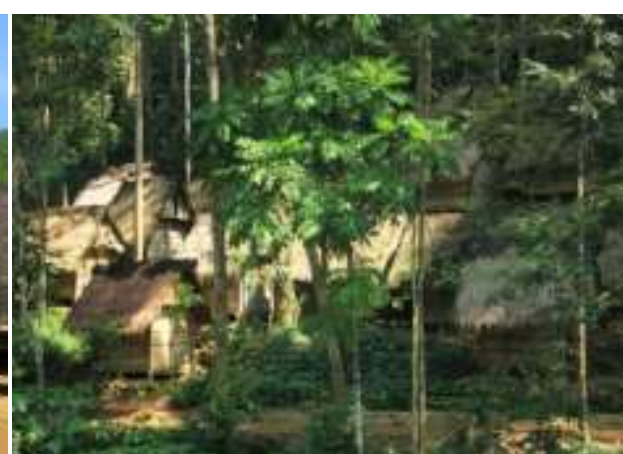

3.(b)

Source: Research result

Picture 3.(a) and 3.(b) The house of the Baduy Tribe that adjusts to the land.

The results of data collection in the field, obtained results:

Table 1. Results of field data collection

\begin{tabular}{|l|l|l|}
\hline No & Respondent & Amount \\
\hline 1 & Baduy Tribe & 18 \\
\hline
\end{tabular}




\begin{tabular}{|l|l|l|}
\hline 2 & Community & 10 \\
\hline 3 & Travelers & 5 \\
\hline Amount & $\mathbf{3 3}$ \\
\hline
\end{tabular}

\subsection{Pikukuh Sapuluh and Pikukuh Karuhun}

Pikukuh is a law or rule that applies to the Baduy Tribe. Pikukuh is divided into two, namely Pikukuh Sapuluh and Pikukuh Karuhun. Pikukuh Sapuluh is a rule also called Dasa Sila, or ten life guidelines that must be held firmly and carried out by the Baduy community. Pikukuh Karuhun is a guideline that contains the rules for carrying out life-based on predetermined and valid rules, also must be adhered to by the Baduy community and outside communities visiting Baduy [2].

Pikukuh Sapuluh includes:

a) Moal megatkeun nyawa nu lian (not killing others)

b) Moal mibanda pangaboga nu lian (do not take other people's stuff)

c) Moal linyok moal bohong (non-default and no lie)

d) Moal mirucaan kana inuman nu matak mabok (do not engage in drunken drinks)

e) Moal midua ati ka nu sejen (do not duplicate the other / polygamy)

f) Moal barang dahar dina waktu nu ka kungkung peting (do not eat at midnight)

g) Moal make kekembangan jeung seuseungitan(not wearing flowers and fragrances)

h) Moal ngageunah-geunah geusan sare (do not stick in sleep)

i) Moal nyukakeun ati ku igel, gamelan, kawih, atawa tembang unpleasant with dance, music, or singing)

j) Moal made emas atawa salaka (not wearing gold or gems).

Pikukuh Karuhun includes:

a) It is prohibited to enter the prohibited forest (leuweung kolot) to cut down trees, open lading or take other forest products.

b) It is prohibited to cut open any type of plants, such as fruit trees, and certain types of trees.

c) Prohibited from using chemical technology, such as using fertilizers, and eradicating pests and suppressing or poisoning fish.

d) Farming must be in accordance with traditional provisions, etc.

The results of interviews conducted to a Jaro Kaduketug village conducted on May 16, 2019, as follows:

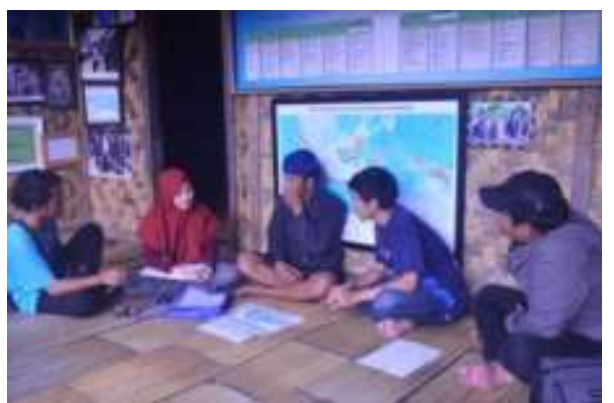

Source: Team documentation

Figure 4. Interview with Jaro Saijan 
According to Jaro Saijan the purpose of Pikukuh is to reconcile the lives of the Baduy community both in the Baduy Luar or in the Baduy Dalam. The results of the research related to Pikukuh are valid, it turns out that the Baduy community, especially the Baduy Luar, is not fully aware of the existence of the Pikukuh, but only certain figures who know it. However, in carrying out the daily lives of the Baduy people, they have implemented the applicable rules, except that they are not widely spread in the Baduy community regarding the rules that are implemented.

People who are allowed to disseminate it include certain figures such as a Jaro (officials under the Puun). This is because of limited access to information between community leaders (important people in Baduy) and the Baduy community. Also, a Puun may not directly interact with the Baduy community, but if there are certain interests and if you want to meet in person must ask permission through their representatives first.

Interviews were also conducted with several speakers, namely the elders or so-called Kokolotan and the Baduy Dalam and Baduy Luar communities related to the existing people.

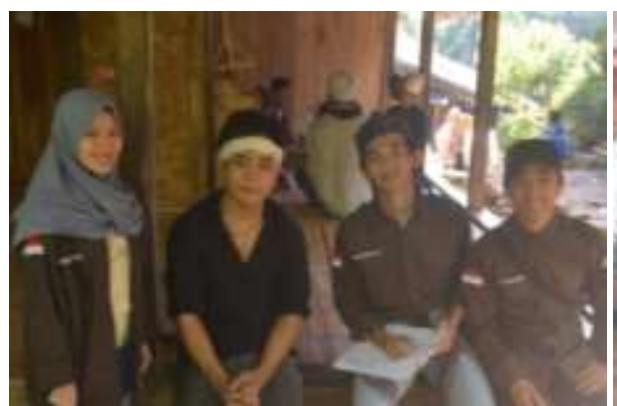

5. (a)

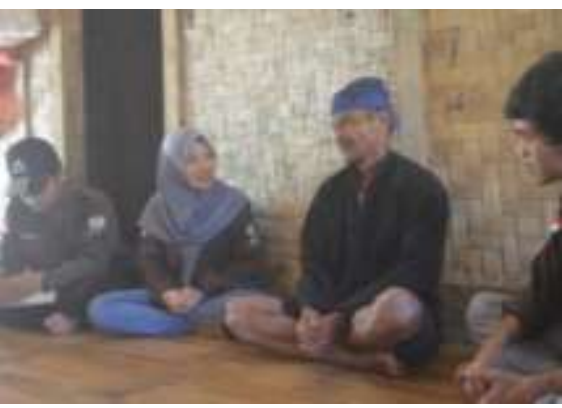

5.(b)

Source: Documentation team

Figure 5. (a) interviews with Kokolotan Baduy Luar,

5. (b) interviews with the Baduy Dalam

In implementing the applicable rules or regulations, there are people who commit violations, based on the results of interviews if there are people who violate Pikukuh, the sanctions imposed apply. If violations are committed once and are known by community leaders, then the offender will be warned, if they continue to violate after being warned, the punishment that is valid and trusted by the Baduy Tribe is the law of karma, the law of karma is considered a punishment that cannot be prevented and will surely occur .

There is no special ritual if the Baduy people want to get out of their tribe, but if there are outside communities who want to enter and become part of the Baduy Tribe, they must eat live chicks. The ritual also applies to Baduy people who have left the Baduy Tribe. According to Jaro Saijan, there were once Baduy people who came out of the Baduy Tribe and became Muslims, but after some time came back again into the Baduy Tribe and performed rituals that became the rules that apply in the Baduy Tribe.

\subsection{Character Inheritance}

Based on the results of research that has been done to the Baduy Tribe in the form of both primary and secondary research, the Baduy have rules related to educating their children, 
which is prohibited from getting formal education (school). This is philosophical, having education or going to school is considered a fool. That is, people who go to school, their minds will be open, which will be oriented towards creating new innovations, ultimately impacting on how to treat nature by not taking care of nature in accordance with the applicable guidelines and rules. Because the Baduy Tribe is a tribe known as a tribe that lives by conserving nature (maintaining and maintaining), then going to school is considered as damaging the life order that has been valid for generations. Also, the Baduy people limit themselves in terms of interacting with outside communities.

Even so, the Baduy community, especially the Baduy Luar community, send their children to formal education and are carried out clandestinely by community leaders. The people who send their children to school think that getting formal education is for themselves, and does not affect the way they treat nature. However, the implementation of the knowledge taught in schools is not fully utilized in the daily life of the Baduy community.

The Baduy Tribe is known as a very conservative tribe in terms of managing and utilizing nature, when it will use nature there is an assessment of nature, for example, thinking correctly, what impact will be caused if the land is utilized.

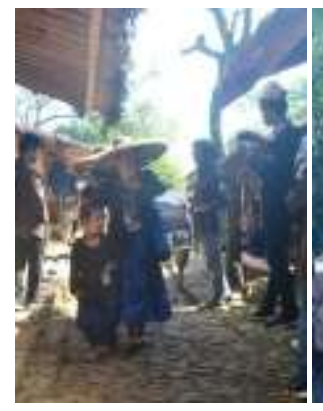

6. (a)

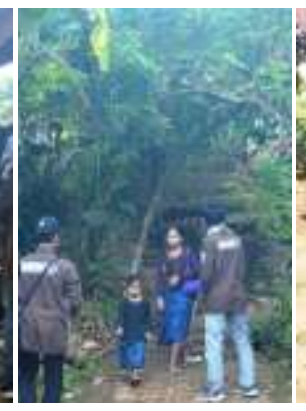

$6 .(\mathrm{b})$

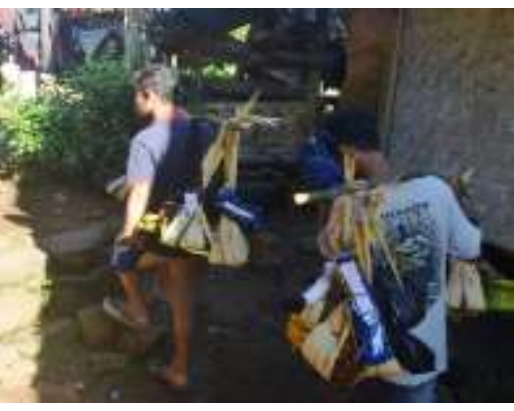

$6 .(\mathrm{c})$

Source: Team documentation

Figure 6. (a), (b), and (c) Inheritance of Baduy Tribe characters from parents to children

Baduy is a tribe that has its own rules to maintain its existence. The thing is by preserving its generation to continue. The way inheritance of the Baduy Tribe character towards its generation began in childhood, the education pursued is an informal dissertation and must be taught to children through parents and nature (living environment). When a child is less than 10 years old, parents are the main educator provided that if a child is a woman educated by her mother, if a child is a boy then a father plays a big role in educating his child. When children are ten years old and above, then interaction with nature will dominate, children begin to be taught to live independently to take advantage of nature and learn how to manage nature well and wisely in accordance with applicable rules. The informal education taught to girls is like weaving, making handicrafts, etc. Whereas boys are taught fortunately to manage fields, hunting, etc. The results of the efforts made to be used as income enhancers for either their families or for themselves.

\subsection{Local Wisdom and External Effects that Enter the Baduy Tribe}

Local wisdom according to Saini [2] is associated with local communities. In foreign languages conceptualized as local policy, local knowledge or local intelligence. Local wisdom 
is also interpreted as a view of life and knowledge as well as various life strategies in the form of activities carried out by local communities in answering various problems in meeting needs, covering all elements of life: religion, science, economics, social organization, language, and communication.

The local wisdom of the Baduy community is carried out to maintain balance and harmony with nature, which creates harmony between the Baduy people who can live side by side with nature. As the principle of the Baduy Society, which reads, "Lojor teu meunag is cut, the teu meunang cottage is connected" (length must not be cut, short should not be connected). There are also other life principles of the Baduy community, namely petatah-petitih which read, "Mountain of the act is melted, Lebak is destroyed" (Mount is not permitted to be merged, Valley is not permitted to be destroyed). The concept of that principle means "nothing changes" (Eka, 2014)

The benefit of the presence of migrants or so-called tourists for the Baduy community is that it can increase family income, the results of informal education are sold at home to attract tourists who come.

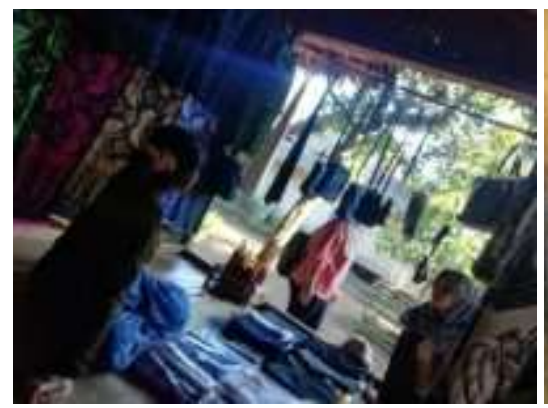

7.(a)

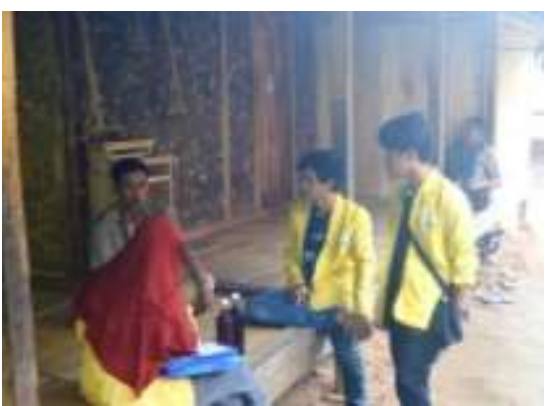

7.(b)

Figure 7. (a) Handicrafts of Baduy Luar Community, 7. (b) Honey as a natural product of Baduy Dalam community sold in Baduy Luar

In addition to having benefits with the presence of migrants, the impact caused by migrants has an influence on culture in the Baduy community which has begun to be disrupted. The impact caused by the way of life of the Baduy community, especially the Baduy Luar which began to be contaminated with the times. Like the use of communication tools in figure 8 .

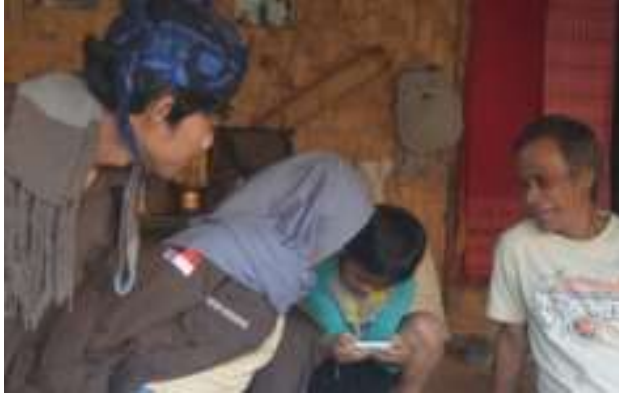

8.(a)

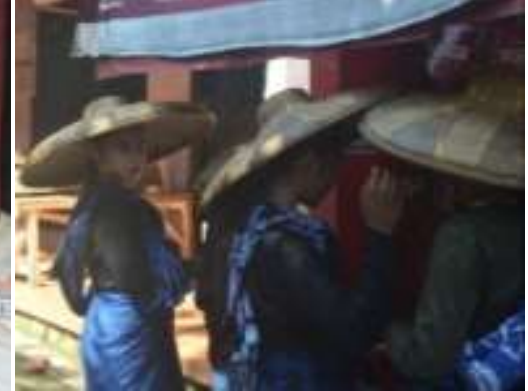

8.(b)

Source: Team documentation

Figure 8. (a) A child playing a game, 8. (b) Baduy's teenager who is buying a sim card. 
The way the people maintain the culture of immigrants, namely immigrants or tourists who come to the Baduy, must obey and obey the rules that apply in the Baduy Tribe and be done without exception.

Values that can be learned from Baduy, among others

1. In the midst of advancing the civilization of the times, Baduy is one of the tribes that still maintains the basic cultural values of ancestral heritage (Pikukuh) that are owned and believed.

2. Behind the regulatory reasons in Baduy, if examined more deeply have logical reasons in life, such as education for children not to enter the forest, which threatens the safety of those who break them. Logically this prohibition protects the forest from damage caused by human activities, besides not disturbing the habitat that lives in the forest.

Local wisdom Baduy tribe becomes part of the way of life to be able to continue to live, even can develop sustainably (sustainable development), such as farming activities that show how to manage nature wisely.

\section{Conclusion}

From the results of the research conducted, it can be concluded that the Baduy Tribe is a tribe that has strict customary rules and is consciously carried out by its people. Even so, there are still violations committed by the community in carrying out daily life from the guidelines on existing Pikukuh, which are still in the stage of tolerance. Sanctions gave when violating the applicable rules, namely tolerance from community leaders, namely warnings if it still violates the Baduy Tribe believes in the law of karma.

In character, inheritance carried out through informal education from parents and nature (the environment) who still adhere to character inheritance to utilize and manage nature appropriately in accordance with Pikukuh or the applicable rules. Has perseverance in terms of maintaining its culture so that it still exists in the midst of an ever-expanding modernization. Immigrants or often referred to as tourists to increase the income of the Baduy community, besides that it also affects the Baduy environment, where the Baduy people, especially the Baduy Luar, are affected. If this continues, the existence of Baduy can fade over time and will disappear into a story.

\section{References}

[1] Sugiyono, "Metode Penelitian Kuantitatif, Kualitatif dan R\&D," Alf. Bandung, 2014.

[2] S. Suparmini, S. Setyawati, and D. R. S. Sumunar, "Pelestarian Lingkungan Masyarakat Baduy Berbasis Kearifan Lokal,” J. Penelit. Hum., vol. 18, no. 1, 2013.

Hardati, Puji., dkk. 2016. Buku Ajar Pendidikan Konservasi. Semarang: Unnes Press.

N, Sora. 2015. Ketahui pengertian Analisis Data Dan Tujuannya. http://www.pengertia nku.net/2015/09/pengertian-analisis-data-dan-tujuannya.html (Accessed on November, 7 2018)

Na'im, Akhsan., Hendry Syahputra. 2010. Kewarganegaraan, Suku Bangsa, Agama, dan Bahasa Sehari-hari Penduduk Indonesia. https://www.bps.go.id/ (Accessed on Oktober, 27 2018) 
Nasehudin, T.S., and Nanang Gozali. 201s2. Metode Penelitian Kuantitatif. Bandung : Pustaka Setia.

Puspavidya, Dinda. 2017. Sejuta Kekayaan Bangsa. https://www.goodnewsfromindonesia.id/ (Accessed on Oktober, 27 2018)

Setiawan, Samhis. 2018. Adat Istiadat: Pengertian, Jenis, Kriteria, Dan Contohnya. https://www.gurupendidikan.co.id/adat-istiadat-dan-contohnya/ (Accessed on Oktober, 29 2018)

Sutoto, S. 2017. Dinamika Transformasi Budaya Belajar Suku Baduy. Jurnal Penelitian Pendidikan, 17(2).

Rahardjo, Mudjia. 2010. Triangulasi dalam Penelitian Kualitatif. https://www.uinmalang.ac.id/r/101001/triangulasi-dalam-penelitian-kualitatif.html (Accessed on Mei, 29 2019)

Riky. Tanpa tahun. Suku Baduy, Bersinergi Dengan Alam Menjaga Aturan Adat. https://www.indonesiakaya.com/jelajah-indonesia/detail/suku-baduy-bersinergidengan-alam-menjaga-aturan-adat (Accessed on Juni ,6 2019)

Yusuf, Eka Novianti. 2014. Kearifan Lokal Suku Baduy.https://ekanoviantiyusuf.wordpress.com/2014/11/30/kearifan-lokal-sukubaduy/ (Accessed on Mei, 27 2019) 